\title{
ANALYSIS OF SOME ASPECTS OF MICROORGANISMS APPLICATION FOR INORGANIC AND MINERALS TREATMENT
}

\author{
V. G. LAZARIEV, A. V. DRAZHNIKOVA, V. I. KARPENKO \\ National Aviation University, Kyiv
}

The article discusses the possibility of integrating multiple methods of biotechnology, namely the elimination of oil pollution using biodegradation, biosorption of heavy metals, obtaining of microbial nanoparticles, technology of microbial fuel cells and others. Authors defined conditions and features of their possible integrated application.

Keywords: biosorption, microbial fuel cells, heavy metal, nanoparticles, utilization, methods integration.

The definition "microbial biotechnology" assumes use of microbial cultures for the production of the final product or their use at different stages of the industrial process.

Modern biotechnology is used in the manufacture of pharmaceuticals, food, fuel, materials, but more often it is about complex organic compounds and raw materials of plant or animal origin.

The aim of this article is estimation of possible integration of some methods and approaches of microorganisms application for treatment of inorganic minerals and raw materials, as well as environmental technologies.

The problem of energy supply is especially actual today. The microbial fuel cells technology becomes widespread in use. This is a progressive and perspective way of generating electricity, the essence of which lies in the fact that microorganisms are used as catalysts for the oxidation of organic and inorganic substances to produce an electrical current. 
Separately should be mentioned the achievements of microbial biotechnology in the biodegradation of oil spills arising from accidents at mining installations or during transportation of liquid hydrocarbons. Today such problems are tasks of ecology that still not fully solved. Many authors have referred to the successful use of microorganisms [1-4].

Biodegradation of petroleum products whenever requires individual solutions related to the nature of pollution and the environment. Respectively, different approaches can be used to solving problems related to oil spills: adding to the soil or water cultures of microorganism [1,2] or adding minerals simultaneously with cultures of microorganisms: nitrogen, phosphorus, potassium [3] and others; application of microbial fuel cell technology to the oil pollution or the use of special biosorbent agents [4].

The use of microorganisms biomass to solve serious environmental problems such as oil spills partly results in damaging of ecosystem as introduction of significant amounts of organisms biomass not typical for the treated area.

Microorganisms and biosorbents used for the biodegradation of oil and petroleum products can also be used for cleaning or pretreatment of certain materials during their production.

However, it is known, that the use of considerable amounts of microbial biomass or biomass of algae and fungi capable to affect the ecological balance.

On the other hand, the unwanted growth of bacteria in the fuel, oil and lubricants (Fig. 1) can lead to machine and mechanisms failure. In some cases, to solve this problem different biocides are used. In comparison with biocides biological methods for the regulation of ecosystem recovery are more safe.

Biosorption of heavy metals and other harmful industrial waste using biomass of bacteria, fungi and algae are widely used and studied by many scientific schools $[5-8,15]$. For example, it is known that the population of algae with a high efficiency capable of binding a wide range of metals of $100 \mathrm{mg}$ of metal per $1 \mathrm{~g}$ of dry biomass [21]. 


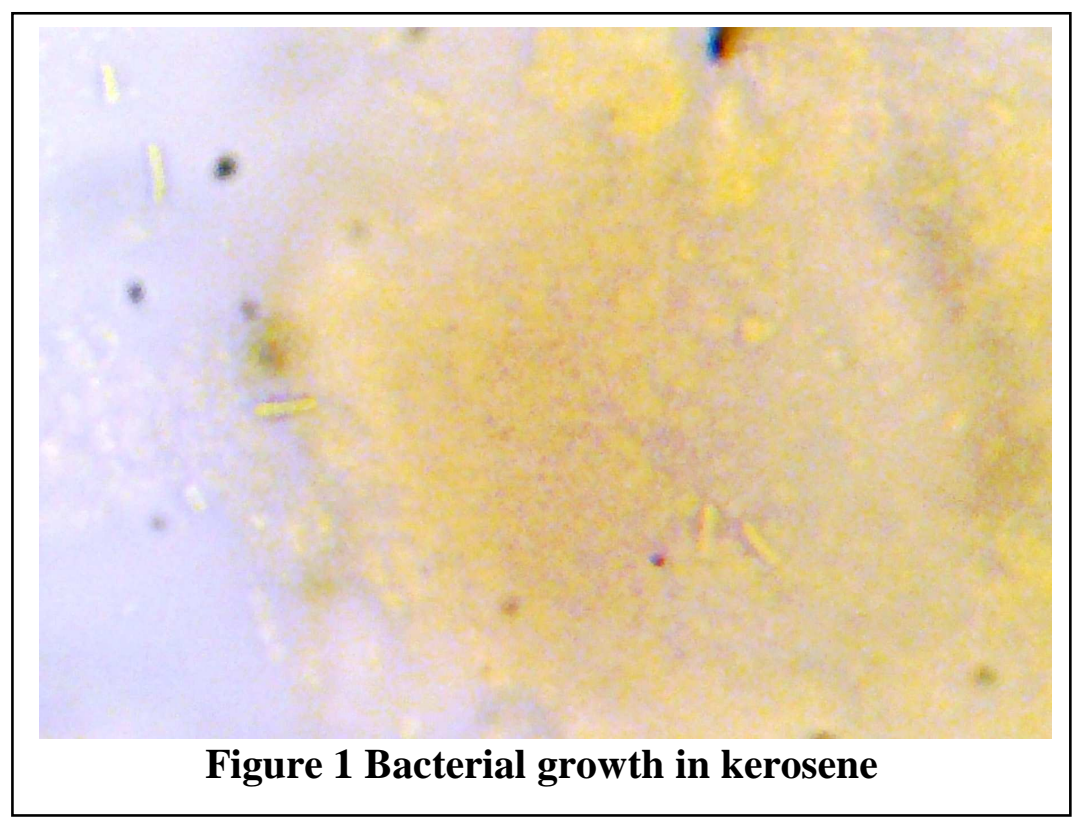

In particular, biosorption of metal is used in the development of methods of extraction and beneficiation of ores and metals for solving problems related to the removal and cleaning of wastes containing heavy metals. Biosorption and bioleaching are well established as industrial methods for enrichment of ores, purification and recycling of industrial wastewater.

The interaction of microorganisms with metals (Fig. 2) and microbial reduction of metals from solutions were considered in $[6,7,10]$.

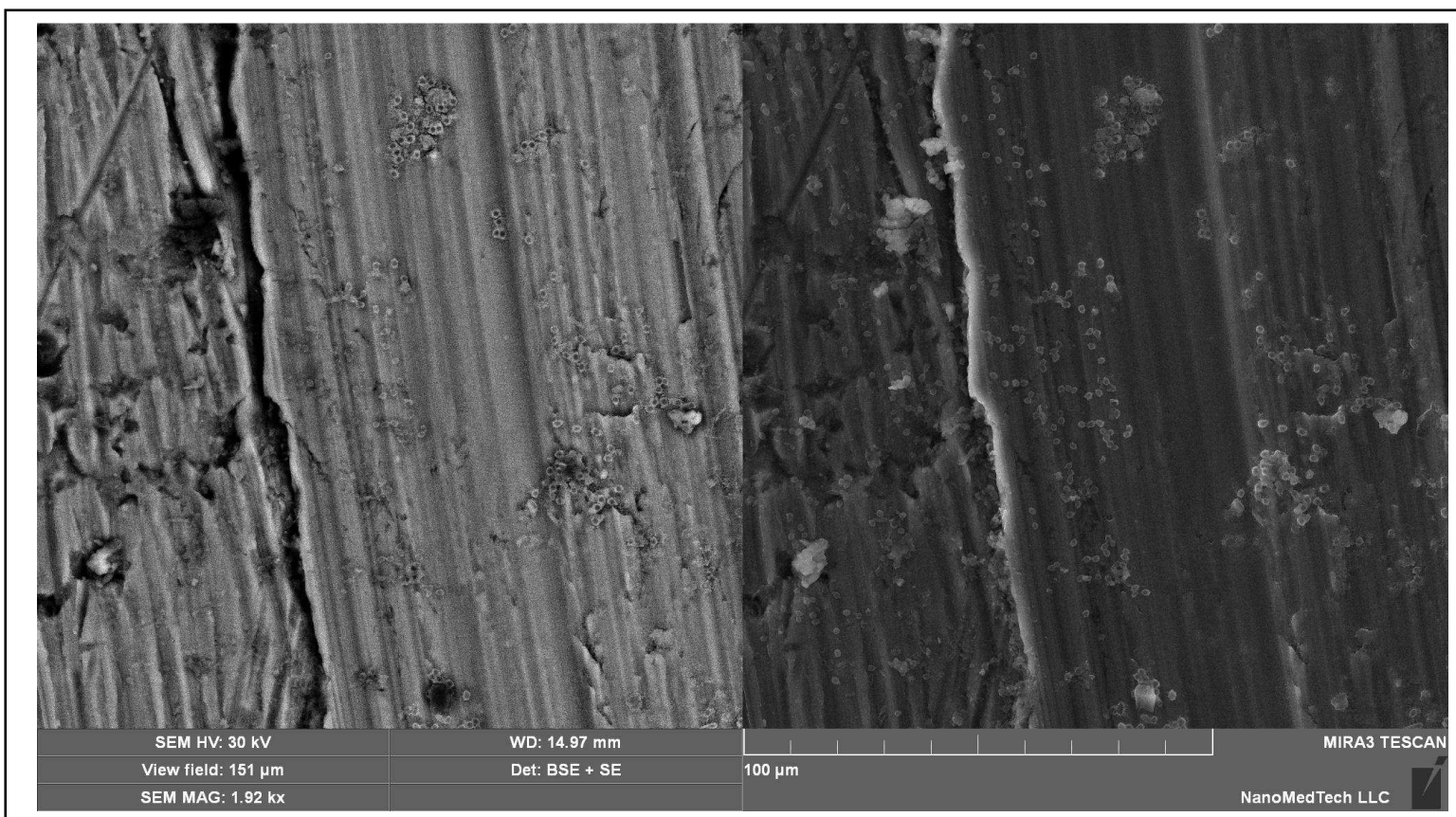

Figure 2 Bacterial growth on metal surface 
Accumulation and immobilization of heavy metals by microorganisms or their associations and microbial extraction of heavy metals from the wastewater are considered by the authors almost as versatile tools for working with many chemical elements [13-15].

Use of bacteria in materials science can be attributed to more exotic fields of application. In this area, as a rule, the use of broad-spectrum biocides allows to avoid the destruction associated with biological corrosion. Microbiological methods are used to improve the properties of building materials $[16,17]$ and in other fields of material science.

Immobilization of microorganisms and their metal salts in the form of nanoparticles is also of great researchers interest today [9, 10]. It is known, that aerobic bacteria of the genus Bacillus widely used in medicine and agriculture are capable of reducing $\mathrm{Ag}^{+}$ions to $\mathrm{Ag}^{0}$ and accumulate metal nanoparticles of 5-15 nm size [22]. Lactic acid bacteria of the genus Lactobacillus promote the formation of nanoparticles of titanium, gold and silver from the precursor ions [23, 24].

Nowadays cultures of microorganisms are used to manufacture the materials and their components, while data on successes embedded in production are less common than the works devoted to biosorption and biodegradation of hazardous industrial waste. For example, attempts to treat the surface of materials by culturing bacteria directly on the surface had only limited success $[11,12]$. Immobilization of the desired substances may, however, be accompanied by unwanted mineralization of other compounds in exceeding desired volume.

Each type of bioprocess we have mentioned, may have its work cycle duration different from others. For example, the process of biosorption of heavy metals or nanoprecipitates formation can only take a few minutes $[5,9,10]$. Biodegradation of oil can last for days and weeks. Microbial fuel cells need to be more long-lasting and research in this area [4, 18-20] usually require tens or even hundreds of days of exposure. Such differences require different technological approaches for bioprocesses implementation, the different inoculation modes, reagent and nutrients supply. 
If we consider several types of parallel bioprocesses, sometimes they can be complementary.

Some wastes and by-products - the biomass of microorganisms and biosorbents also require utilization. An example is the yeast biomass which is a byproduct of alcohol production. It is possible to use yeast biomass for biosorption of heavy metals from solutions or as part of the biosorbent. Disposal of microbial biomass simultaneously - the organization of constant replacement of biosorbent with fresh. Thus, the efficiency of uranium sorption biomass by dead yeast Saccharomyces cerevisiae cells is $0,58 \mathrm{mmol} / \mathrm{g}$ and zinc $-0,56 \mathrm{mmol} / \mathrm{g}$. It was found, that $60 \%$ of the uranium adsorbed in the first 15 minutes of microorganisms contact with a solution of metal [25].

Issues of control and regulation of microorganism species diversity and biomass at work in the open soil can be resolved not only by the use of biocides, but also the introduction of microbial cultures.

Outlined above data about the features of the integration of different methods of microbial biotechnology certainly have concise character. The authors only have attempted to analyze accumulated over the past decades extensive factual material in order to select and group the most promising methods of applied microbiology with a view to their possible technological integration.

\section{CONCLUSIONS}

Summarizing the data about the features of the integration of several methods of microbial biotechnology, we can conclude about the prospect of engineering and applied research in this field. These works are already carried out at the department of biotechnology of the National Aviation University. Positive results have been obtained on the isolation of bacteria-destructors of fuel, formation of microbial nanoparticles of heavy metals, utilization of yeast biomass - waste of the some food industries.

Integration of several methods within a single production can help to improve the concept of sewage treatment of industrial enterprises with increasing of their 
environmental safety. Also, the combined use of techniques such as biosorption and biodegradation, microbial fuel cells, bioleaching can generate a more universal solutions to contemporary environmental problems.

\section{REFERENCES}

1. Бондарець Ю. В. Використання екологічно-доцільних технологій для ликвідації нафто розливів / Ю. В. Бондарець, О. Л. Матвєєва // Экология предприятия. - 2013. - №12. - С. 64-69.

2. Матвєєва О. Л. Біодеградація вуглеводнів як вирішення проблеми нафтового забруднення / О. Л. Матвєєва, О. Р. Алієва // 4 Всеукр. 3’їзд екологів 3 міжнар. участю (Екологія / Ecology 2013), 25-27 вер. 2013 р.: зб. наук. статей. - Вінниця: Видавництво-друкарня «ДІЛО», 2013. - С. 94-96.

3. Shabir G. Biodegradation of kerosene in soil by a mixed bacterial culture under different nutrient conditions / Shabir G., Afzala M., Anwar F. et al. // International Biodeterioration \& Biodegradation. - 2008. - Vol. 61. - P. 161-166.

4. Microbial fuel cell in enhancing anaerobic biodegradation of diesel / [Morrisa J. M., Jinb S., Crimid B., Prudend A.] / Chemical Engineering Journal. - 2009. - Vol. 146. - P. 161-167.

5. Voleski B. Biosorbtion of heavy metals. Review / B. Voleski, Z. R. Holan // Biotechnology Prog. - 1995. - Vol. 11. - P. 235-250.

6. Environmental Biotechnology. Concepts and Applications / Ed. by H.-J. Jördening, J. Winter. - Weinheim: WILEY-VCH Verlag GmbH \& Co. KGaA, 2005. $-463 \mathrm{p}$.

7. Evans G. M. Environmental Biotechnology. Theory and Application / 2nd ed. / Evans G. M., Furlong J. C. - Chichester: Wiley, 2010. - 290 p.

8. Das N. Biosorption of heavy metals - an overview / Das N., Vimala R., Karthika R. // Indian Journal of Biotechnology. - 2008. - Vol. 7. - P. 159-169.

9. Lazariev V. G. Nanoparticles Containing Tungsten and Molybdenum in Microbial Biofilms / [Lazariev V. G., Labunets V. F., Boretska M. A. et al.] // 
Проблеми екологічної біотехнології. - 2013. - № 1. - Режим доступу: http://nbuv.gov.ua/j-pdf/peb 2013 1 8.pdf

10.Sag Y. Recent Trends in the Biosorption of Heavy Metals: A Review / Y. Sag, T. Kutsal // Biotechnol. Bioprocess Eng. - 2001. - Vol. 6. - P. 376-385.

11.Микробная модификация поверхности материалов / [Кудрин А. П., Лабунец В. Ф., Лазарев В. Г. и др.] // Восточно-Европейский журнал передовых технологий. - 2005. - № 5 (17). - С. 68-75.

12.Biotechnology perspectives in surface engineering. Review / [Labunets V. F., Lazariev V. G., Belevtsev R. J. et al.] // Proceedings of the 5-th World congress "Aviation in the XXI-st century" - "Safety in Aviation and Space Technologies", September 25-27, 2012. - Vol. 2. - K.: NAU, 2012. - P. 4.1.26 - 4.1.29.

13.Таширев А. Б. Извлечение “смешанными микробными сообществами” широкого спектра металлов из сточных вод г. Киева / Таширев А. Б., Шевель В. М. // Мікробіол. журн. - 2004. - Т. 66, № 5. - С. 80-86.

14.Таширев А. Б. Концепция интегральных механизмов аккумуляции металлов синтрофными микробными ассоциациями / А. Б. Таширев // Мікробіол. журн. - 1999. - Т. 61, № 5. - С. 78-84.

15.McHale A. P. Microbial biosorption of metals: Potential in the treatment of metal pollution / A. P. McHale, S. McHale // Biotechnology Advances. - 1994. Vol. 12. - Is. 4. - P. 647-652.

16.Microbial impact on building materials: an overview / [Gaylarde C., Ribas Silva M., Warscheid Th.] / Materials and Structures. - 2003. - Vol. 36. - Is. 5. P. 342-352.

17.De Muyncka W. Microbial carbonate precipitation in construction materials: A review / De Muyncka W., De Beliea N., Verstraeteb W. / Ecological Engineering. - 2010. - Vol. 36. - Is. 2. - P. 118-136.

18.Biffinger J. C. The influence of acidity on microbial fuel cells containing Shewanella oneidensis / Biffinger J. C., Pietron J., Bretschger O. et al. // Biosensors and Bioelectronics. - 2008. - Vol. 24. - P. 900-905. 
19.Kus E. The bacterial battery and the effect of different exposure conditions on biofilm properties / E. Kus, Nealsonb K., Mansfeld F. et al. // Electrochimica Acta. - 2008. - Vol. 54. - Is. 1. - P. 47-52.

20.Logan B. E. Electricity-producing bacterial communities in microbial fuel cells. Review / B. E. Logan, Regan J. M. // Trends in Microbiology. - 2006. Vol.14. - Is.12. - P. 512-518.

21.Volesky B. Biosorption of heavy metals / B. Volesky, Z. R. Holan // Biotechnology Progress. - 1995. - Vol. 11. - P. 235-250.

22.Microbial synthesis of silver nanoparticles by Bacillus sp. / [Pugazhenthiran N., Anandan S., Kathiravan G. et al.] // J. Nanopart. Res. - 2009. Vol. 11. - P. 1811-1815.

23.Prasad K. Lactobacillus assisted synthesis of titanium nanoparticles / Prasad K., Jha A. K., Kulkarni A. R. // Nanoscale Res. Lett. - 2007. - Vol. 2. P. 248-250.

24.Nair B. Coalescence of nanoclusters and formation of submicron crystallites assisted by Lactobacillus strains / B. Nair, T. Pradeep // Cryst. Growth Des. - 2002. Vol.2. - P. 293-298.

25.Volesky B. Biosorption of heavy metals by Saccharomyces cerevisiae / B. Volesky, H. A. May-Phillips // Applied Microbiology and Biotechnology. - 1995. - Vol. 42. - P. 797-806.

\title{
АНАЛІЗ ДЕЯКИХ АСПЕКТІВ ЗАСТОСУВАННЯ МІКРООРГАНІЗМІВ ДЛЯ ОБРОБКИ НЕОРГАНІЧНИХ РЕЧОВИН І МІНЕРАЛІВ
}

\author{
В. Г. ЛАЗАРСВ, А. В. ДРАЖНІКОВА, В. І. КАРПЕНКО \\ Наиіональний авіаційний університет, м. Київ
}

У статті обговорюється можливість інтеграчиї декількох методів біотехнології, а саме: ліквідація нафтових забруднень за допомогою біодеструкторів, біосорбиія важких металів, отримання мікробних 
наночастинок, технологія мікробних паливних елементів та ін. Визначено умови та особливості їх можсливого сумісного використання.

Ключові слова: біосорбиія, паливний елемент, важкі метали, наночастинки, утилізачія, інтеграчія методів.

\title{
АНАЛИЗ НЕКОТОРЫХ АСПЕКТОВ ПРИМЕНЕНИЯ МИКРООРГАНИЗМОВ ДЛЯ ПЕРЕРАБОТКИ НЕОРГАНИЧЕСКИХ ВЕЩЕСТВ И МИНЕРАЛОВ
}

\author{
В. Г. ЛАЗАРЕВ, А. В. ДРАЖНИКОВА, В. И. КАРПЕНКО \\ Национальный авиащионный университет, г. Киев
}

В статье обсуждается возможность интеграции нескольких методов биотехнологии, а именно: ликвидащия нефтяных загрязнений при помощи биодеструкторов, биосорбция тяжелых металлов, получение микробных наночастии, технология микробных топливных элементов и др. Определены условия и особенности их возможного совместного использования.

Ключевые слова: биосорбция, топливный элемент, тяжелые металль, наночастицы, утилизация, интеграчия методов. 